\title{
Evaluasi Perancangan Sensor Fiber Optik Plastik untuk Pengukuran Stress dan Strain
}

\author{
Eni Sugiarti, ${ }^{*}$ Resetiana Dwi Desiati, Prabowo Puranto, Edi Tri Astuti, dan Tomi Budi Waluyo \\ Pusat Penelitian Fisika - LIPI \\ Komplek Puspiptek Serpong - Tangerang 15314, Indonesia
}

\begin{abstract}
Intisari
Sensor strain digunakan untuk mengukur perubahan strain akibat stress pada suatu bahan. Dalam penelitian ini, telah dirancang sensor strain menggunakan fiber optik dari bahan dielektris plastik dengan teknik pencacatan. Teknik yang dipakai adalah untuk melihat perubahan intensitas cahaya yang terdeteksi sebagai akibat dari stress yang diterima fiber optik. Pengamatan dalam perancangan sensor fiber optik menggunakan PC mikroskop sehingga struktur permukaan fiber yang kecil dan halus dapat terlihat. Untuk mengetahui besaran strain akibat stress yang terukur dibutuhkan sumber cahaya laser, fotodetektor, rangkaian amplifier, modul akuisisi data (DAQ) dan PC. Evaluasi hasil perancangan sensor dilakukan dengan uji tarik (tensile) fiber optik yang diletakkan pada spesimen menggunakan mesin universal tensile meter (UTM).
\end{abstract}

KATA KUNCI: sensor strain, fiber optik, stress, UTM.

\section{PENDAHULUAN}

Perkembangan fiber optik yang pesat menyebabkan aplikasi fiber optik saat ini tidak hanya dimanfaatkan sebagai media transmisi tetapi juga sebagai sensor. Sensor strain dan stress menggunakan fiber optik memiliki kelebihan dibandingkan dengan sensor lain karena fiber optik itu sendiri unggul dalam ukuran yang kecil, tahan terhadap interferensi elektromagnetik dan radiasi cahaya serta tidak terpengaruh pada sifat bahan sehingga dapat dilekatkan dengan bahan komposit secara non-obstrusive (tanpa desakan) [1].

Berbagai sistem sensor fiber optik untuk mengukur strain dan stress telah banyak dikembangkan. Sistem sensor tersebut adalah sensor FBG (Fibre Bragg Grating) [2] yang prinsipnya adalah mengukur perubahan intensitas sinyal optik yang direfleksikan sebagai fungsi dari perubahan panjang gelombang dan strain pada fiber optik, sensor FPI (Fabry Perot Interferometer) [3] berdasarkan multi refleksi fabry perot yang berinterferensi, sensor ESPC (embedded sensor protection system)[4] yang mengukur perubahan strain dan strain akibat perubahan struktur yang terdeteksi serta masih banyak lagi. Semua sistem tersebut tentunya memiliki kelebihan dan kekurangan masing-masing.

Terdapat perbedaan embedded fiber optic sensor lainnya dengan sistem yang akan dirancang. Sistem sensor ini lebih sederhana karena tidak membutuhkan teknik demodulasi untuk mengolah sinyal dengan menggunakan spektrum optik analiser, melainkan hanya membutuhkan peralatan seperti transmitter dan receiver yang dalam hal ini adalah laser He$\mathrm{Ne}$ dan fotodioda.

Dengan keunggulan karakteristik fiber optik maka pada paper ini akan dibahas mengenai rancangan sensor strain

*E-MAIL: enis002@lipi.go.id dan stress menggunakan fiber optik plastik. Plastic Optical Fiber (POF) menjadi alternatif selain Glass Fiber Optic (GOF) yang dapat mengurangi transmisi sinyal yang hilang dan hanya mengandalkan modulasi intensitas cahaya sebagai sensor yang akan mendapat perlakuan seperti tarikan (tensile).

\section{DASAR TEORI}

Fiber optik merupakan pemandu gelombang (waveguide) dari bahan dielektris (gelas dan plastik) yang mentransmisikan cahaya. Berdasarkan hukum Snellius untuk transmisi optik bahwa cahaya yang dipantulkan akan mengalami pembengkokan diantara 2 media, dalam hal ini adalah core /inti dan cladding /pelindung dari fiber optik. Masing-masing media tersebut memiliki index refraktif (n). Jika sudut yang terbentuk lebih besar dari sudut kritis, maka terjadi refleksi total dan tidak ada cahaya yang masuk ke medium lain seperti terlihat pada Gambar 1a. Sedangkan jika pada medium terdapat celah (Gambar 1b) maka sebagian berkas cahaya akan hilang keluar sehingga akan mengurangi dayanya sesuai dengan persamaan:

$$
\operatorname{Power}(d B)={ }^{10} \log _{10} \frac{P_{\text {out }}}{P_{\text {in }}}
$$

Kemampuan fiber untuk mentransfer cahaya ditunjukkan oleh persamaan Numerical Aparture (NA) yang dapat dituliskan sebagai berikut:

$$
N A_{\text {out }}=\sqrt{n_{1}^{2}-n_{2}^{2}}
$$

Namun untuk fiber yang diberi perlakuan seperti pembengkokan berlaku persamaan NA yang berbeda yaitu:

$$
N A_{\text {out }}=\sqrt{n_{1}^{2}-n_{2}^{2}\left(1+\frac{2 a}{2 R}\right)^{2}}
$$




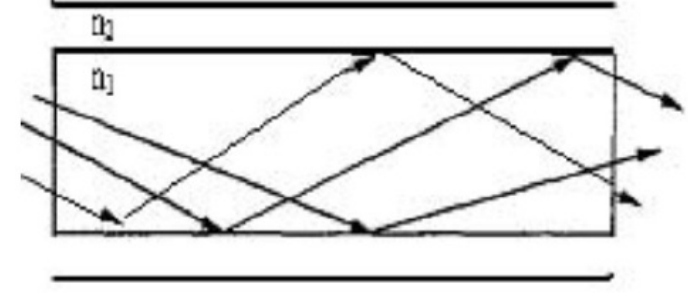

(a)

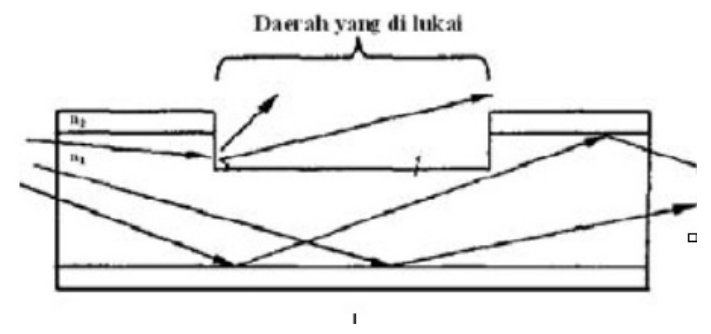

(b)

Gambar 1: (a). Berkas cahaya pada kondisi FO normal (lurus dan tidak dilukai),(b). Berkas cahaya pada kondisi FO dilukai

dengan $\mathrm{n}_{1}$ = indeks refraktif inti fiber, $\mathrm{n}_{2}=$ indeks refraktif pelindung fiber, $\mathrm{R}=$ Radius pembengkokan, $\mathrm{a}=$ Radius fiber.

Untuk mengetahui besarnya perubahan strain akibat stress maka fiber optik diberi perlakuan dengan uji tarik. Persamaan untuk stress dan strain yang berlaku saat objek di tarik (tensile) adalah berdasarkan deformasi yang dialami suatu benda yang mengalami gaya. Strain, $\epsilon$, adalah besar deformasi persatuan panjang,

$$
\epsilon=\frac{\Delta L}{L}
$$

sedangkan stress $(\mathrm{S})$ adalah gaya persatuan luas,

$$
S=\frac{F}{A}
$$

Strain awal akan berbanding lurus dengan besarnya stress. Namun setelah stress ditiadakan, strain akan hilang. Kondisi seperti ini dinamakan kondisi balik (reversible). Strain linier yang mampu balik tersebut disebut dengan strain elastik. Untuk strain elastik berlaku persamaan modulus elastik atau modulus Young, E, dengan persamaan:

$$
E=\frac{S}{\epsilon}
$$

Kekuatan tarik (tensile strength) suatu bahan ditetapkan dengan membagi gaya maksimum dengan luas penampang semula. Dengan demikian dimensi kekuatan tarik akan sama dengan besaran stress dari Pers.5.

\section{METODOLOGI PENELITIAN}

Dalam perancangan sensor strain dan stress menggunakan fiber optik digunakan beberapa metode untuk membandingkan respon perubahan intensitas cahaya akibat stress yang diterima fiber optik.

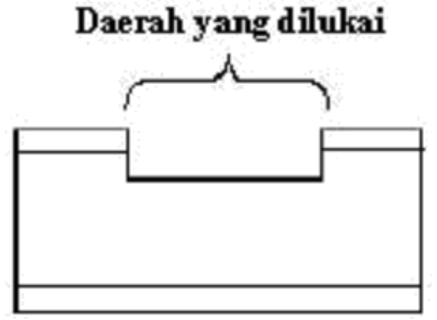

(a)

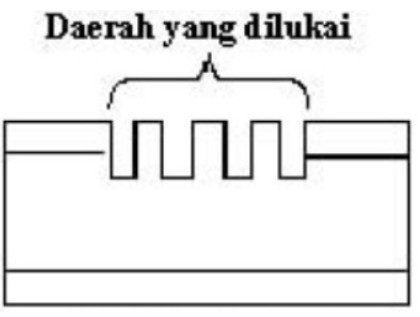

(b)

Gambar 2: (a). Fiber Optik cacat tunggal, (b).Fiber Optik cacat banyak

\section{A. Metoda Perancangan Sensor}

Sensor strain dan stress menggunakan fiber optik plastik (POF) sepanjang $\pm 2 \mathrm{~m}$. Sensor dirancang dengan teknik pencacatan fiber optik secara tunggal (Gambar 2a) dan banyak (multi point) pada Gambar 2b yang masing-masing dilakukan ditengah POF sepanjang $\pm 2 \mathrm{~cm}$. Pengamatan dalam perancangan sensor fiber optik menggunakan alat bantu PC mikroskop sehingga struktur permukaan fiber yang kecil dan halus dapat terlihat (Gambar 3).

\section{B. Metoda Preparasi Sensor strain dan Benda Uji}

Sebelum melakukan pengambilan data, batang sensor fiber optik diletakkan pada benda uji paduan aluminium tipe A5052P. Pelat aluminium ini dipotong menurut dengan ukuran yang disesuaikan dengan kemampuan load cell dari mesin uji tarik UTM. Secara diagramatik bentuk benda uji adalah seperti Gambar 4.

Teknik meletakkan sensor fiber optik pada benda uji dilakukan dengan memposisikan bentuk penampang geometri fiber baik secara lurus (Gambar 5a), lengkung ke dalam (Gambar 5b) dan lengkung ke luar (Gambar 5c). Sensor direkatkan pada benda uji menggunakan lem cyanoacrylate. Agar proses pengambilan data tidak terganggu maka tidak seluruh permukaan benda uji direkatkan fiber optik. Ilustrasi penempatannya akan ditunjukan pada Gambar 6.

\section{Metoda pengambilan data}

Dalam pengambilan data, sensor fiber optik membutuhkan sumber cahaya laser yaitu laser He-Ne dengan $\lambda=632,5 \mathrm{~nm}$, 


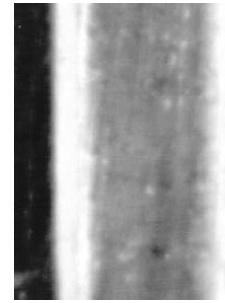

(a)

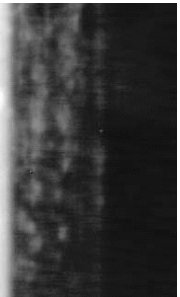

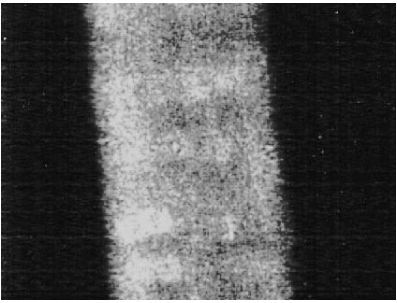

(b)

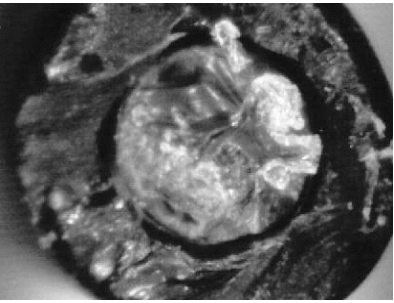

(c)

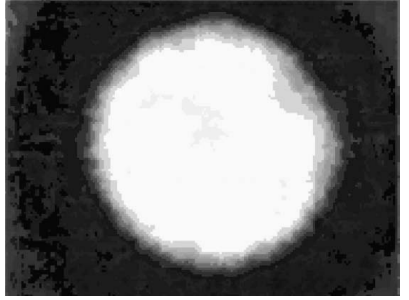

(d)

Gambar 3: (a). Pengecekan penampang irisan fiber yang telah dicacat tanpa diberi sumber laser, (b). Pengecekan penampang irisan fiber yang telah dicacat dengan sumber laser, (c). Pengecekan penampang ujung fiber tanpa diberi sumber laser, (d). Pengecekan penampang ujung fiber dengan sumber laser.

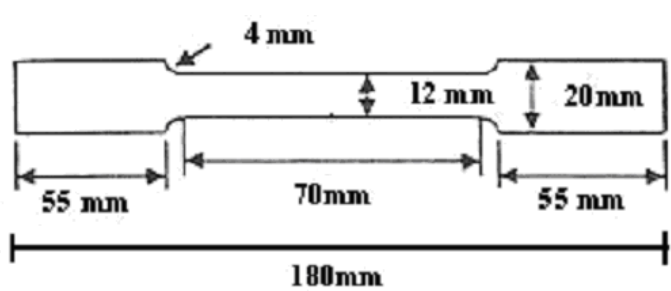

(a)

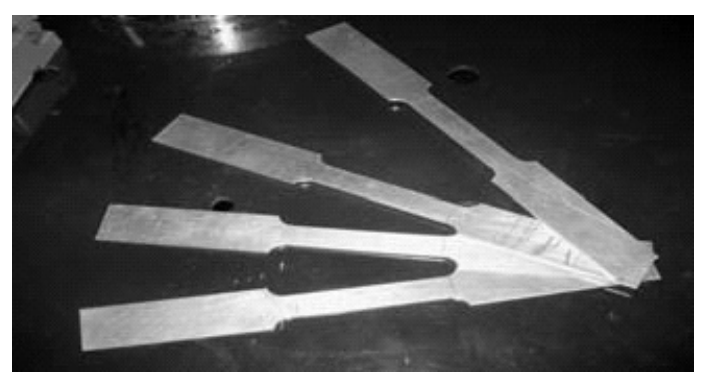

(b)

Gambar 4: Potongan benda uji yang digunakan pada eksperimen sensorfiber optik.

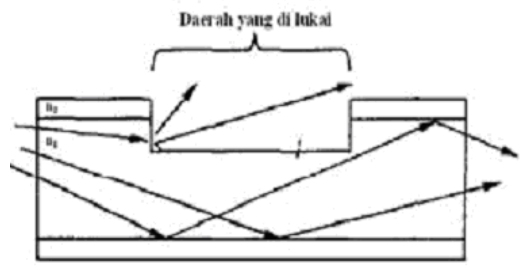

(a)

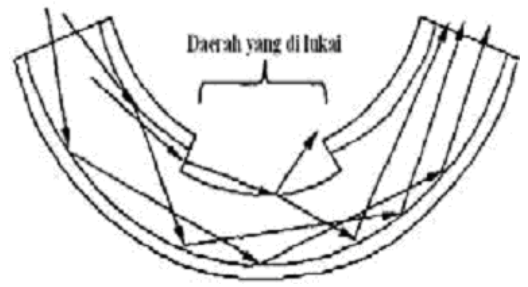

(b)

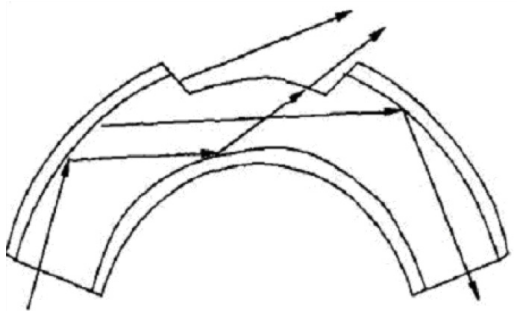

(c)

Gambar 5: (a). Penampang geometri fiber lurus,(b). Penampang geometri fiber lengkung ke dalam,(c). Penampang geometri fiber lengkung ke luar.

\section{HASIL DAN DISKUSI}

Analisa untuk mengetahui respon posisi geometri sensor fiber optik pada benda uji terhadap strain dan stress telah dilakukan secara manual dengan membengkokan fiber yang telah dicacati. Dari Gambar 8 dapat diketahui bahwa saat fiber dibengkokan ke dalam sensitivitas sensor terhadap stress dan strain lebih besar dibandingkan saat fiber tersebut dibengkokan ke luar atau lurus. Hal ini ditunjukkan dengan besarnya tegangan yang diperoleh yaitu untuk geometri fiber optik lurus adalah $\pm 2,5 \mathrm{~V}$, geometri fiber optik lengkung ke dalam sebesar $\pm 2,6 \mathrm{~V}$ dan geometri lengkung ke luar 


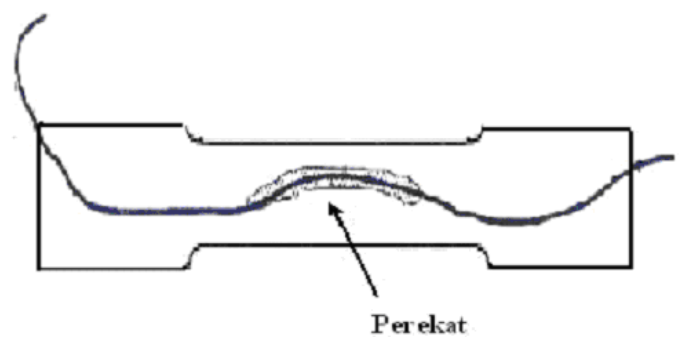

(a)

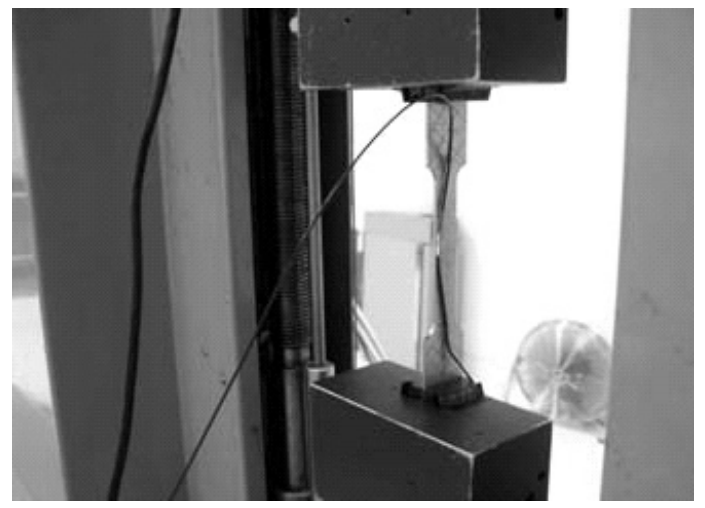

(b)

Gambar 6: (a). Ilustrasi penempatan sensor fiber optik pada benda uji, (b). Posisi Fiber Optik lekuk ke dalam yang ditempelkan pada benda uji

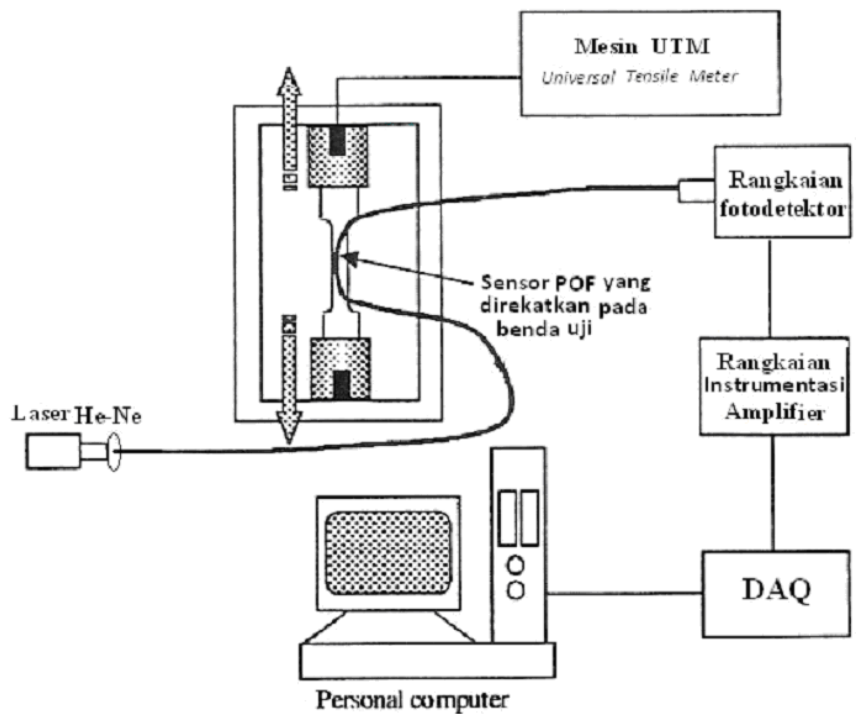

Gambar 7: Skema Sistem Sensor Fiber Optik Plastik.

adalah paling kecil yaitu $\pm 1,4 \mathrm{~V}$. Perbedaan tegangan yang dihasilkan disebabkan oleh perbedaan besarnya intensitas cahaya yang bocor pada keadaan geometri tertentu.

Dengan metode pengujian posisi geometri fiber optik maka untuk eksperimen uji tarik (tensile) dengan UTM, responsitas sensor fiber optik terhadap strain dan stress diambil dengan melengkungkan fiber ke arah dalam yang diletakkan pada benda uji. Selain geometri fiber, hal lain yang perlu diper-

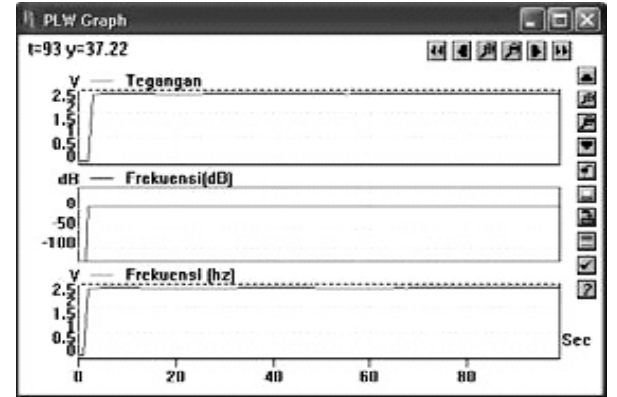

(a)

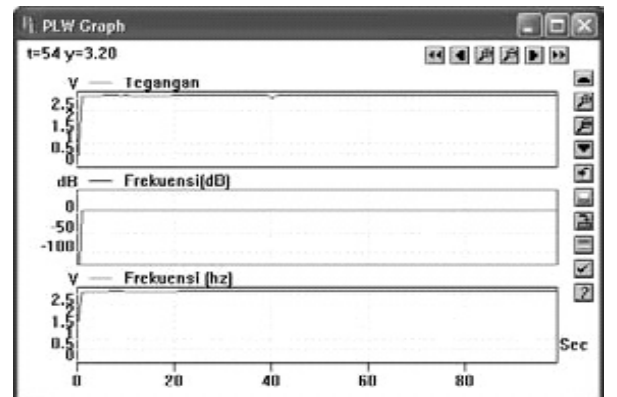

(b)

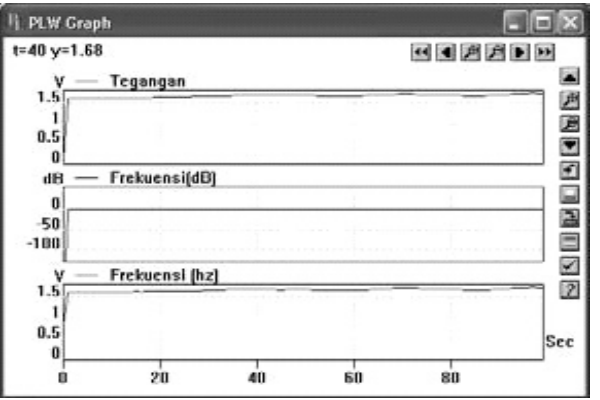

(c)

Gambar 8: (a). Geometri fiber Optik Lurus ,(b).Geometri fiber optik lengkung ke dalam,(c). Geometri fiber optik lengkung ke luar.

hatikan adalah karakteristik bahan yang digunakan sebagai benda uji yaitu pelat aluminium A5052P. Bahan yang akan diberi perlakuan tentunya mendapat gaya yang besarnya akan mempengaruhi deformasi bahan tersebut. Deformasi yang dapat terjadi pada bahan adalah deformasi elastik yaitu deformasi linier dimana bahan dapat kembali ke kondisi semula (ductility) yang ditunjukkan pada daerah elastis (Gambar 9) dan deformasi plastik yang terjadi pada daerah plastis dimana saat kondisi ini bahan sudah patah dan tidak dapat kembali ke bentuk semula.

Pencatatan data eksperimen dilakukan oleh X-Y plotter dari mesin uji tarik, UTM, dan PC dengan perangkat lunak yang telah dirancang berbasis modul akuisisi data. Hasil yang terukur oleh X-Y plotter pada Gambar 10 merupakan responsitas sistem sensor fiber optik terhadap perubahan stress dan strain yang terjadi selama benda uji mengalami deformasi elastik.

Pada daerah elastik, bahan tidak akan patah tetapi akan terjadi perubahan panjang akibat gaya yang diberikan. Be- 


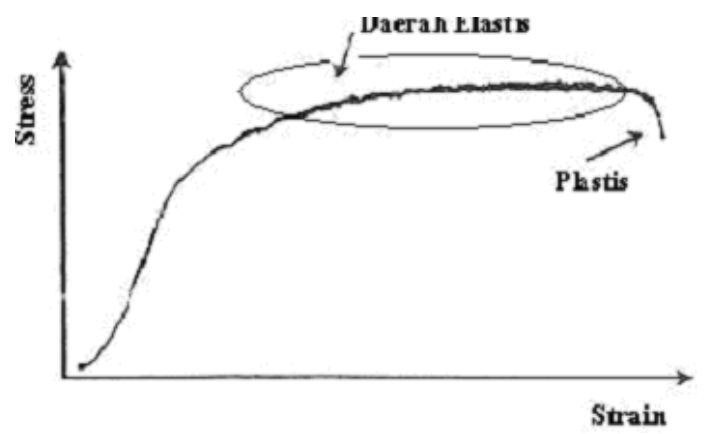

Gambar 9: Contoh kurva strain VS stress dari pelat aluminium A5052P.

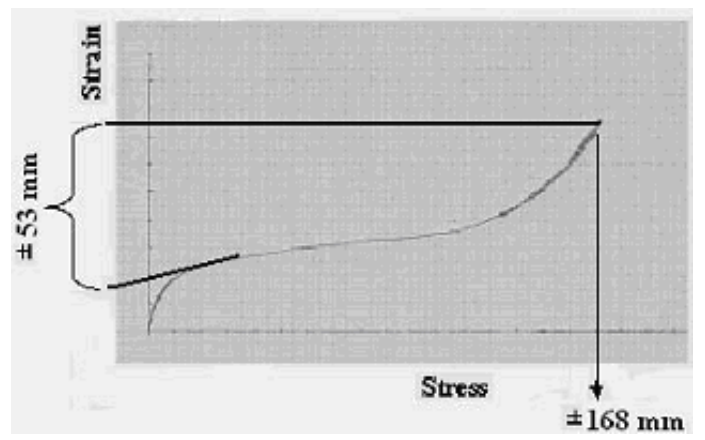

Gambar 10: Kurva stress Vs strain Pelat Aluminium A5052P yang dicatat oleh X-Y plotter UTM.

sarnya perpanjangan merupakan strain yang terukur, maka berdasarkan Gambar 10 diperoleh strain yaitu sebesar \pm 5,3 mm. Sedangkan stress diketahui dengan korelasi perbandingan gaya persatuan luas pada mesin UTM dengan X-Y plotter UTM yaitu sebesar $\pm 5376 \mathrm{~N} / \mathrm{mm}^{2}$.

Hasil yang diperoleh pada PC dapat diketahui secara real time dengan sistem sensor fiber optik yang secara kompak dirangkaikan. Gambar 11 menunjukkan perubahan strain sensor fiber optik yang diuji tarik menggunakan UTM dengan selang waktu tertentu. Tegangan yang diperoleh merupakan strain yang terukur sebagai akibat perubahan intensitas cahaya yang bocor dari fiber optik. Tegangan mula-mula yang terukur adalah $\pm 2,65 \mathrm{~V}$ dan tegangan akhirnya adalah sebesar $\pm 2,05 \mathrm{~V}$. Dengan demikian terjadi perubahan tegangan sebesar $0,6 \mathrm{~V}$ atau dengan kata lain terjadi perubahan strain sebesar $\pm 8,8 \mu \mathrm{m} / \mathrm{mV}$. Hal ini menunjukkan bahwa selama benda diuji ditarik, sensor fiber optik mengalami penurunan tegangan sebagai akibat intensitas cahaya yang bocor makin bertambah.

\section{SIMPULAN}

Dari pembahasan yang telah diuraikan maka evaluasi perancangan sensor fiber optik plastik untuk pengukuran stress dan strain dapat ditarik beberapa kesimpulan yaitu :

1. Teknik pencacatan fiber optik plastik (POF) yang telah dirancang memiliki sensitivitas terhadap perubahan strain dan stress.

2. Posisi geometri sensor fiber optik yang lengkung ke dalam memiliki sensitivitas yang baik dibandingkan lengkung ke luar ataupun lurus saat sensor tersebut ditempelkan pada benda yang akan diuji dengan tegangan maksimal yang terdeteksi yaitu sebesar $\pm 2,6 \mathrm{~V}$.

3. Metode pengujian dari sistem sensor fiber optik adalah dengan uji tarik menggunakan mesin UTM pada benda uji yang telah direkatkan sensor fiber optik.

4. Pencatatan data eksperimen dilakukan oleh X-Y plotter dari mesin uji tarik, UTM, dan PC dengan perangkat lunak yang telah dirancang berbasis modul akuisisii data

5. Berdasarkan X-Y plotter UTM diketahui bahwa strain yang diperoleh yaitu sebesar $\pm 5,3 \mathrm{~mm}$, sedangkan stressnya adalah $\pm 5376 \mathrm{~N} / \mathrm{mm}^{2}$.

6. Hasil yang diketahui dari PC adalah perubahan tegangan sebesar $0,6 \mathrm{~V}$ atau dengan kata lain terjadi perubahan strain sebesar $\pm 8,8 \mathrm{~m} / \mathrm{mV}$.

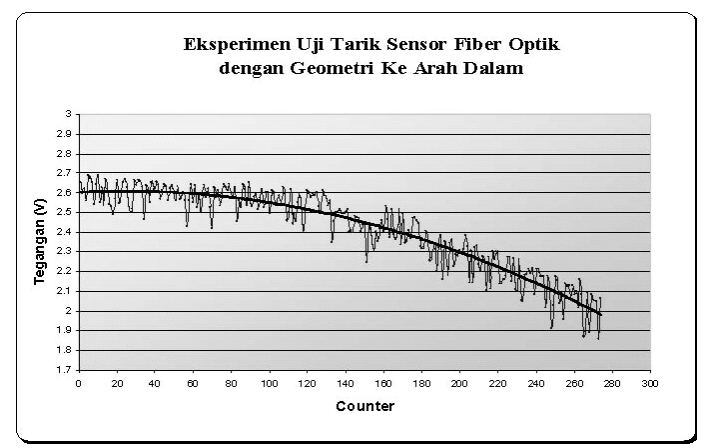

Gambar 11: Grafik banyaknya data terhadap tegangan sebagai respon uji tarik sensor fiber optik dengan geometri lengkung ke dalam.
[1] Leng Jinsong and Anand Asundi, Sensor and Actuators A 103, 330-340 (2003).

[2] Liu J.G., Schmidt hattenberger, G.Borm, Measurement 32, 151161 (2002).

[3] Tuck J, Christopher, Richard Haque dan Crispin Doyle, Measurement Science Technology 17, 2206-2212 (2006).
[4] Leng Jinsong, D Winter, R A Barnes, G C Mays dan G F Fernando, Smart Mater.Struct. 15, 302-308 (2006).

[5] K.S.C Kuang, W J Cantwell dan P J Scully, Meas.Sci.Technol. 13, 1523-1534 (2002). 